\title{
The moths (Lepidoptera) of Glasgow Botanic Gardens
}

\author{
R.B. Weddle \\ 89 Novar Drive, Glasgow G12 9SS \\ E-mail: richard@canto.plus.com
}

\begin{abstract}
The moths that have been recorded in the Glasgow Botanic Gardens, Scotland over the years are reviewed and assessed in the context of the City of Glasgow, the vice-county of Lanarkshire (VC77), and the U.K. in general. The additions to the list since the last review in 1999 are highlighted. Some rare and endangered species are reported, though the comparatively low frequency of sightings of several normally common species suggests that the site is generally under-recorded. The same is true of Glasgow and Lanarkshire in general.
\end{abstract}

\section{INTRODUCTION}

There are few records of moths in the Glasgow Botanic Gardens (GBG) prior to 1980-1999 when Dr Robin Knill-Jones did some moth-trapping there. Full details of the catches are not available, though a few were included in insect lists published by Iain Christie and Geoff Hancock in The Glasgow Naturalist at the time. Though many of these give the location explicitly as "Glasgow Botanic Gardens", there are others from "Glasgow, West End" some of which could also be from GBG. Subsequently, Graham Irving did some trapping in 2002, and there are further records from Bat \& Moth Night events in August 2006-2009. However, most of the information presented here is derived from trapping done by the author between August 2009 and September 2018, approximately monthly during the warmer months. There are also records of moths over the years that have been found by other recorders and other methods such as field observations of day-flying moths or leaf-mines.

In Hancock's Hidden Wildlife account forming part of the original On the Wildside survey, only 11 moth species are listed, four of which are attributed to KnillJones (Hancock, 1999). The present account amplifies the information on some of these, and adds a considerable number of species to the list.

A list of all species that have been recorded in GBG (including the Kelvin and North Kelvin slopes) can be found at www.gnhs.org.uk/biodiversity/GBG_splist.pdf together with the years of the earliest and latest records and the total number of records of each moth (this is not the same as the total number of individual moths found, as any one record could comprise many individuals of that species).
At the end of 2018 the species list included 201 distinct moth species; this may be compared with the 859 moths which had been recorded in Glasgow as a whole at the same date. In this account I shall comment on just a few of those 201 species, which seem to be significant in one way or another. More detail on any of the records can be obtained from Glasgow Museums Biological Record Centre, and Scottish distribution maps of the various moths can be found at www.eastscotlandbutterflies.org.uk/mothflighttimes.html

In the 2017 Bioblitz (including the Bat \& Moth Night) 15 species of moth were recorded; two of these (rosy rustic and bulrush wainscot) are highlighted in the following sections.

\section{U.K. BAP SPECIES IN GBG}

Many moths are "species of conservation concern" on account of a marked decline in their numbers in recent years, and are listed as U.K. Biodiversity Action Plan (BAP) species. These species are also included in the Scottish Biodiversity List for the same reasons, even though it seems that, in many cases, species that are in decline in the U.K. generally may be still relatively abundant in Scotland or parts of Scotland.

In the following notes percentage declines over "the last 35 years" are taken from DEFRA (2016) and declines over "the last 40 years" are from Butterfly Conservation (2013); the declines are derived mainly from counts of moths from Rothamsted traps across the U.K. over the period starting 1968. In most cases the exact cause of the decline is unknown, but possibilities - or contributory factors - include agricultural intensification, habitat fragmentation, inappropriate management such as "tidying", use of pesticides and fertilisers, lightpollution, and climate change. See Butterfly Conservation (2013) for further discussion of these factors.

In the following notes, names and dates of observations refer to records held in Glasgow Museums Biological Record Centre database (and the database of the National Moth Recording Scheme) unless otherwise referenced. It should be noted that all cited numbers of "Glasgow records" include numbers of records from GBG. The taxonomic nomenclature is based on Agassiz et al. (2013) with published updates added in 2017 by Les Hill (National Moth Recording Scheme). 


\section{Hepialidae}

Ghost moth (Hepialus humuli)

$62 \%$ decline over the last 40 years; common in Scotland; four GBG records, 27 Glasgow records. Larvae in roots of grasses and other herbs including nettles (Urtica spp.).

\section{Geometridae}

Small phoenix (Ecliptopera silaceata)

$77 \%$ decline over the last 35 years; common in U.K. generally; 79 Glasgow records, seven in GBG (20022016). Larvae feed on various species of willowherb (Chamaenerion spp.).

\section{Latticed heath (Chiasmia clathrata)}

$85 \%$ decline over the last 40 years; common in the south of Scotland, absent or stray in the north, but range expanding; one GBG record, 103 Glasgow records. Larvae feed on clovers (Trifolium spp.) and lucerne (Medicago sativa).

\section{Noctuidae}

Mouse moth (Amphipyra tragopoginis)

$85 \%$ decline over the last 40 years; common in the east of Scotland, scarcer in the west; numbers have declined; four GBG records, 79 Glasgow records. Larvae feed on a wide range of herbaceous plants including sallow (Salix spp.) and hawthorn (Crataegus spp.).

\section{Mottled rustic (Caradrina morpheus)}

84\% decline over the last 40 years; common in England and in south and east Scotland; one GBG record (R.B. Weddle (RBW) in 2017), 16 Glasgow records. Larvae feed on a wide range of herbaceous plants including nettle and docks (Rumex spp.).

\section{Rustic (Hoplodrina blanda)}

$78 \%$ decline over the last 40 years; widespread in Scotland on low ground and coast; 29 Glasgow records; only one in GBG (RBW in 2016, confirmed by R. Leverton), though there is also a "West End" record (R. Knill-Jones in 1981) which may possibly be from GBG. As this species is easily confused with the uncertain (Hoplodrina octogenaria) some of these records may be better described as "rustic/uncertain agg.", though several are confirmed (there are three further Glasgow records confirmed as uncertain, all from identified locations in the north west). Larvae feed on a wide range of herbaceous plants including chickweeds, docks and plantains (Plantaginaceae). Dalglish (1901) described its abundance in the Clyde area as "local and rare" (listed as Caradrina taraxaci).

Rosy rustic (Hydraecia micacea)

$86 \%$ decline over the last 40 years; common in Scotland; 25 Glasgow records, including five from GBG (two of which were in separate traps run for the 2017 Bat \& Moth Night). Larvae feed on a wide range of herbaceous plants including docks and plantains.

\section{Ear moth (Amphipoea oculea)}

$71 \%$ decline over the last 35 years; common in U.K. generally; recorded once at GBG (R. Sutcliffe in 2004), also a second record (R. Sutcliffe in 2004) as A. oculea agg. only one other record of oculea agg. in Glasgow (oculea is the commonest species in this group). Larvae feed on stems and roots of grasses (as do other members of the Amphipoea group).

Dusky brocade (Apamea remissa)

$76 \%$ decline over the last 35 years; common in Scotland; 34 Glasgow records, two in GBG. Larvae feed on grasses such as reed canary-grass (Phalaris arundinacea) and common couch (Elymus repens).

\section{Centre-barred sallow (Atethmia centrago)}

$74 \%$ decline over the last 40 years; occasional though widespread in Scotland, particularly in the southern half; woodland and hedgerow; two records from GBG, in 2001 and 2006 (both R. Sutcliffe); there are also more recent records in the West End of Glasgow (six Glasgow records in all), and more recently still in South Lanarkshire and East Dunbartonshire. Larvae feed on ash. Regarded as a good indicator of what is happening in the wider environment (DEFRA, 2016).

Dark brocade (Mniotype adusta)

$78 \%$ decline over the last 35 years, most markedly in the southern half of England; common and widely distributed in Scotland; one GBG record (RBW in 2014), five Glasgow records. Larvae feed on various grasses and a variety of low plants.

Garden dart (Euxoa nigricans)

98\% decline over the last 40 years; widespread but scarce in south-west and east Scotland; apparently declining; two GBG records, four Glasgow records. Dalglish (1901) described its incidence in the Clyde area as "not common; [occurring] at ragwort and sugar", which suggests that the adults are most often found by torchlight while they are nectaring; however, through the 1980s John Morgan found it regularly in small numbers in the Penilee area of Paisley, and so it appears to have been locally common there. Larvae feed on clovers, docks, and plantains.

Small square-spot (Diarsia rubi)

$87 \%$ decline over the last 40 years; common in U.K. generally; 14 records in Glasgow, three in GBG. Larvae feed on a wide range of herbaceous plants including dandelion (Taraxacum spp.), docks and foxglove (Digitalis purpurea), and so might be expected to be recorded more frequently.

\section{GBG MOTHS UNRECORDED ELSEWHERE IN GLASGOW Nepticulidae}

Ectoedemia decentella

Recorded once (N. Gregory in 2008); common in England, though so far found only in Lanarkshire and Fife in Scotland. Larvae feed on sycamore "keys" (Acer pseudoplatanus), so very likely to be underrecorded.

\section{Gracillariidae}

Povolnya leucapennella 
Recorded once (N. Gregory et al. in 2009); local across U.K. Larvae feed inside "cones" rolled in the leaves of oaks (Quercus spp).

\section{Gelechiidae}

Aproaerema anthyllidella

Recorded once (RK-J in 1982); common in England, more local in Scotland. Larvae feed in blotch-mines in kidney vetch (Anthyllis vulneraria) and other low herbs that grow in a similar habitat.

\section{Saturniidae}

Atlas moth (Attacus atlas)

Introduced: a large moth of forests of south-east Asia; the GBG specimen was introduced as a caterpillar from India and emerged as an adult in May 1916 (McLachlan, 1919).

\section{Geometridae}

Lesser treble-bar (Aplocera efformata)

Recorded once (by R. Sutcliffe in 2004). In Scotland commonest in West Lothian and Falkirk (on bings and in quarries) but regularly found in recent years in Motherwell (D. Abraham in 2013-17). Larvae feed on St. John's-wort (Hypericum perforatum).

\section{Sphingidae}

Small elephant hawk-moth (Deilephila porcellus) Recorded once (G. Irving, 2002); local across U.K., with an eastern bias in Scotland. Larvae feed on bedstraws, also on rosebay willowherb (Chamaenerion angustifolium) and purple loosestrife (Lythrum salicaria).

\section{NOTES ON OTHER GBG MOTHS}

Since Hancock (1999) there have been no further records in GBG of Adela reaumurella, spindle ermine (Yponomeuta cagnagella), rhomboid tortrix (Acleris rhombana), or July highflier (Hydriomena furcata). However, there have been three records of Agriphila straminella, seven of Agriphila tristella, eight of brimstone (Opisthograptis luteolata), 32 of large yellow underwing (Noctua pronuba), and three of silver Y (Autographa gamma).

Of these, the micro-moths are likely to be the less recorded (which will apply to the GBG species list in general), as they tended to be ignored until recent years when good identification guides became available; also they become worn quite quickly and therefore more difficult to identify. The large yellow underwing can occur in large numbers in the trap: on occasions there have been 100 or more. The silver $\mathrm{Y}$ is an immigrant, which arrives annually in varying numbers; the numbers found in the GBG trap probably depend on whether it is operating at a time when the moths are on the move.

\section{Gracillariidae}

\section{Azalea leaf-miner (Caloptilia azaleella)}

Native to east Asia; an accidental introduction to U.K., on azalea plants (Rhododendron spp.). Hancock (1999) states that Knill-Jones' record of blister-mines attributed to this species at GBG may be the only known occurrence in Scotland; unfortunately no date is cited. Knill-Jones also recorded this species at Garscube (Glasgow/East Dunbartonshire) in 1983. Its presence in GBG was confirmed in 2016 by the presence of an adult in the moth trap, and there are further records of adults from the urban area adjacent to Linn Park in the same year (by G. Williamson). An adult was also recorded in 2015 in Dumbarton (by A. Kerr). The species is probably very under-recorded in this area generally.

\section{Yponomeutidae}

Bird-cherry ermine (Yponomeuta evonymella)

A common species in the area, the caterpillars of this small but attractive moth are gregarious and notable for spinning protective webs over large parts of birdcherries (Prunus padus), sometimes completely defoliating them - as happened annually on a tree near the Flint Mill bridge on the Kelvin Walkway downstream of GBG (the tree was removed in recent years). The first record in GBG was in 1981 (by R. Knill-Jones). There are no subsequent records until August 2015, and it has appeared in small numbers in the trap in August of each subsequent year. There are 81 records from Glasgow.

\section{Tortricidae}

Light brown apple moth (Epiphyas postvittana)

A native of Australia first recorded in the U.K. in Cornwall in 1936, and gradually moving through the U.K. (perhaps with the aid of horticultural suppliers and garden centres). Classified as invasive in U.K., though here it is not an orchard pest, seeming to prefer a miscellany of garden trees, shrubs, and herbaceous plants. Found fairly regularly in the GBG trap, normally in small numbers, though there were 18 individuals on one date in May 2017; however, there is no evidence that it is a significant pest there. There is only one record in the Clyde area of Scotland outwith the Glasgow City boundary, and that was in Bishopbriggs near the Forth and Clyde canal (A. Winthrop in 2015).

\section{Geometridae}

Gem (Nycterosea obstipata)

Migrant; occasional scattered records mainly in the south of Scotland; one record in GBG, 2017 (R.B. Weddle, det. R. Leverton); the only other Glasgow record is in Kelvingrove Park at the end of the 19th century (by G.W. Ord, labelled Melanippe fluviata); also in Kilmacolm (by N. Gregory in 2007).

\section{Noctuidae}

Bulrush wainscot (Nonagria typhae)

Scarce in the west of Scotland; the GBG specimen is the first adult found in Glasgow, and was discovered by a participant in the 2017 Bat \& Moth Night. A larva was found in a Typha stem at Possil Marsh by R.A. Crowson in 1988; Crowson had previously found larvae at Dalzell Estate in 1983, and there are recent records of adults from Motherwell, Bishopbriggs and Lochwinnoch.

\section{CONCLUSIONS}

The aim of the above remarks is to put some of the GBG moth records in the context of the records in Glasgow 
and the wider area as a whole. It has to be said, though, that there are not, and in the last 100 years have never been, many recorders moth-trapping on a regular basis. Currently there are only about seven locations in Glasgow where moth traps are being run more or less regularly, three of those are in the West End, and all are in predominantly urban environments. Moth records from the other parts of Glasgow in recent years have come from one-off trapping events, and ad hoc records of day-flying moths or caterpillars. It is therefore clear that GBG and Glasgow as a whole are very underrecorded (the same is also true of most other groups of insects with the possible exception of butterflies).

There is of course a relatively restricted range of habitats in GBG compared with the city as a whole. However, there is undoubtedly much more scope for additions to the GBG moth list for a number of reasons: the moth trap is situated, for security reasons, among illuminated glasshouses, which is not ideal; not all moths come to the mercury-vapour lamps used in the trap; and GBG contain plant species which do not occur (or are uncommon) elsewhere in Glasgow. So it is likely that further species could be added by trapping in other locations within GBG - though on the few occasions this has been tried by the author, there were no previously unrecorded species - or by other methods such as searching for caterpillars, leaf-mines and other larval signs, or by techniques such as "sugaring" where moths are attracted to sweet aromatic preparations (see Butterfly Conservation https://butterflyconservation.org/ for details). The same methods could also be applied in other areas of Glasgow where no systematic moth recording has been done.

\section{ACKNOWLEDGEMENTS}

I am grateful to Ewen Donaldson and his staff at Glasgow Botanic Gardens for putting out the trap when requested; to the following recorders: Neil Gregory, Geoff Hancock, Graham Irving, Robin Knill-Jones, Chris Pantrey, and Richard Sutcliffe; to Glasgow Museums Biological Record Centre for contextual records from other vice-counties (which includes those parts of Glasgow in Renfrewshire (VC76) and Dunbartonshire (VC99)); and to Richard Sutcliffe again for helpful comments on this note.

\section{REFERENCES}

Agassiz, D.J.L., Beavan, S.D. \& Heckford, R.J. (2013). A Checklist of the Lepidoptera of the British Isles. Royal Entomological Society, London.

Butterfly Conservation (2013). The State of Britain's Larger Moths 2013. https://doi.org/10.1515/9781400846900

Dalglish, A.A. (1901). Macro-Lepidoptera. In: Scott Elliot, G.F., Laurie, M. \& Murdoch, J.B. (Editors). Fauna, Flora and Geology of the Clyde Area, pp. 223-245. British Association for the Advancement of Science, Glasgow. https://doi.org/10.5962/bhl.title.1392

DEFRA (Department for Environment, Food and Rural Affairs). (2016). http://jncc.defra.gov.uk/page-5169
Hancock, E.G. (1999). Hidden wildlife: the resident population of invertebrates. The Glasgow Naturalist 23(4), 62.

McLachlan, R. (1919). [Untitled]. The Glasgow Naturalist 8(3), 91. 